Int. J. Electrochem. Sci., 11 (2016) 4598 - 4610

International Journal of

ELECTROCHEMICAL

SCIENCE

www.electrochemsci.org

\title{
Corrosion of Newly Manufactured Nanocrystalline Al and Two of its Alloys in stagnant 4.0\% NaCl Solutions
}

\author{
El-Sayed M. Sherif ${ }^{1,2,{ }^{*}}$, Hany S. Abdo ${ }^{1,3}$, Jabair A. Mohammed ${ }^{1}$, Abdulhakim A. Almajid ${ }^{1,4}$ and \\ Asiful H. Seikh ${ }^{1}$ \\ ${ }^{1}$ Center of Excellence for Research in Engineering Materials (CEREM), Advanced Manufacturing \\ Institute, King Saud University, P. O. Box 800, Al-Riyadh 11421, Saudi Arabia \\ ${ }^{2}$ Electrochemistry and Corrosion Laboratory, Department of Physical Chemistry, National Research \\ Centre (NRC), Dokki, 12622 Cairo, Egypt \\ ${ }^{3}$ Mechanical Design and Materials Department, Faculty of Energy Engineering, Aswan University, \\ Aswan 81521, Egypt \\ ${ }^{4}$ Mechanical Engineering Department, King Saud University, P.D. Box 800, Riyadh 11421, Saudi \\ Arabia \\ *E-mail: esherif@ksu.edu.sa, emsherif@gmail.com
}

doi: $10.20964 / 2016.06 .21$

Received: 2 March 2016 / Accepted: 12 April 2016 / Published: 4 May 2016

In this study, pure nanocrystalline $\mathrm{Al}$ and two of its alloys; namely $\mathrm{Al}-7 \% \mathrm{Cu}$ and $\mathrm{Al}-7 \% \mathrm{Cu}-3 \% \mathrm{Ti}$, were manufactured after $5.0 \mathrm{~h}$ milling period of time using mechanical attrition. All samples were sintered for $3 \mathrm{~min}$ at $600{ }^{\circ} \mathrm{C}$ using high frequency heat induction sintering furnace. The sizes of the crystallite and the hardness of the manufactured $\mathrm{Al}$ and its alloys were determined using X-ray diffractometer and Vickers hardness $(\mathrm{VH})$ investigations, respectively. The effect of adding $7 \% \mathrm{Cu}$ and $7 \% \mathrm{Cu}+3 \% \mathrm{Ti}$ on the corrosion of the fabricated pure aluminum in $4.0 \% \mathrm{NaCl}$ solutions was carried out. The corrosion tests used in this study were cyclic polarization, change of current with time, and electrochemical impedance spectroscopy measurements. It was found that the presence of $\mathrm{Cu}$ increases the hardness of $\mathrm{Al}$ and this effect was highly increased in the presence of $\mathrm{Cu}$ and $\mathrm{Ti}$ together with $\mathrm{Al}$. Moreover, adding $\mathrm{Cu}$ and further $\mathrm{Cu}$ and $\mathrm{Ti}$ increased the corrosion of $\mathrm{Al}$. Adding $\mathrm{Cu}$ and $\mathrm{Cu}$ with $\mathrm{Ti}$ was found to increase the corrosion current, corrosion rate, anodic current, and cathodic current of Al. All results were consistent with each other and proved that the presence of $\mathrm{Cu}$ and $\mathrm{Ti}$ increases the hardness as well as the corrosion behavior of Al.

Keywords: nanocrystalline; Al alloys; corrosion; mechanical attrition; Vickers hardness; EIS; polarization 


\section{FULL TEXT}

(C) 2016 The Authors. Published by ESG (www.electrochemsci.org). This article is an open access article distributed under the terms and conditions of the Creative Commons Attribution license (http://creativecommons.org/licenses/by/4.0/). 